\section{Sara Fabijanić} Igor Miholjek

Sara Fabijanić, fabijanicsara@gmail.com

Igor Miholjek, Hrvatski restauratorski zavod Odjel za podvodnu arheologiju imiholjek@hrz.hr

Prethodno priopćenje / Preliminary communication

Primljen / Received: 17. 5. 2021.

UDK: 902.034(497.5-3 Dalmacija)"652" DOI: https://doi.org/10.17018/portal.2021.12

\section{Zaštita podvodnih arheoloških} nalazišta in situ - primjeri upotrebe zaštitnih kaveza

SAžETAK: Podmorje istočnog Jadrana obiluje arheološkim nalazištima i olupinama iz svih povijesnih razdoblja, počevši od prapovijesti pa do novog vijeka. Međutim, bez obzira na postojanje zakona i pravilnika koji jasno definiraju tko i pod kojim uvjetima smije pristupiti podvodnoj kulturnoj baštini, kao i na propisane prekršajne odredbe za nedozvoljene radnje, brojna su podvodna arheološka nalazišta devastirana, a s njih je ilegalno odnesen vrijedan arheološki materijal. Kako su se postojeći pravilnici pokazali nedostatnom metodom zaštite, pristupilo se fizičkoj zaštiti in situ, koja se i prema UNESCO-voj Konvenciji o zaštiti podvodne kulturne baštine ističe kao prvi izbor. Metalni se kavezi u hrvatskom podmorju u ovu svrhu primjenjuju od 1990. godine, a do danas je na ovaj način zaštićeno osam arheoloških nalazišta: Za Planiku i Saplun u arhipelagu Lastovskog otočja, Koromašno na otoku Žirju, otok Supetar ispred Cavtata, Klačine na otoku Mljetu, Vlaška Mala na otoku Pagu, Sorinj na otoku Rabu i Buje u blizini Umaga. U radu će se dati pregled spomenutih nalazišta i metoda izrade samih kaveza koje su se tijekom godina značajno unaprijedile. Naglasak će biti na definiranju prednosti i nedostataka ovog načina zaštite, imajući na umu razinu ugroženosti pojedinih nalazišta s obzirom na njihovu lokaciju, problem održavanja kaveza te njihovu primjenu u turističke i promidžbene svrhe.

KLJUČNE RIJEČI: zaštita podvodnih arheoloških nalazišta, istočni Jadran, metalni kavezi, brodolom, antika, devastacija, ugroženost, amfore, kulturna baština

\section{Povijesne prilike nastanka metode zaštite pomoću zaštitnih kaveza}

Republički zavod za zaštitu spomenika kulture Republike Hrvatske proveo je još 1969 . godine prve pokušaje stvaranja sveobuhvatnog sustava zaštite podvodne kulturne baštine Republike Hrvatske. Iste je godine u Šibeniku održan prvi radni sastanak na kojem su sudjelovali predstavnici vladinih i javnih institucija čije područje rada uključuje zaštitu podvodne kulturne baštine. ${ }^{1} \mathrm{Na}$ sastanku je naglašena potreba za konzerviranjem arheološkog materijala s podvodnih arheoloških nalazišta, na kopnu ili in situ.
Kao najprikladnije rješenje izglasana je fizička zaštita in situ, barem dok se ne ostvare odgovarajući uvjeti za konzerviranje izvađenih arheoloških nalaza. Godine 2001. UNESCO je donio Konvenciju o zaštiti podvodne kulturne baštine, u kojoj je upravo konzerviranje in situ predložena kao prvi izbor po pitanju zaštite ${ }^{2}$ te koju je Hrvatska 2004. godine ratificirala kao treća zemlja u svijetu. ${ }^{3}$ Kao sljedeći korak u definiranju načina zaštite podvodnih arheoloških nalazišta treba izdvojiti ulomak unutar projektnog prijedloga koji su zajedno sastavili Arheološki zavod Odsjeka za arheologiju Filozofskog fakulteta u Zagrebu i spomenuti 


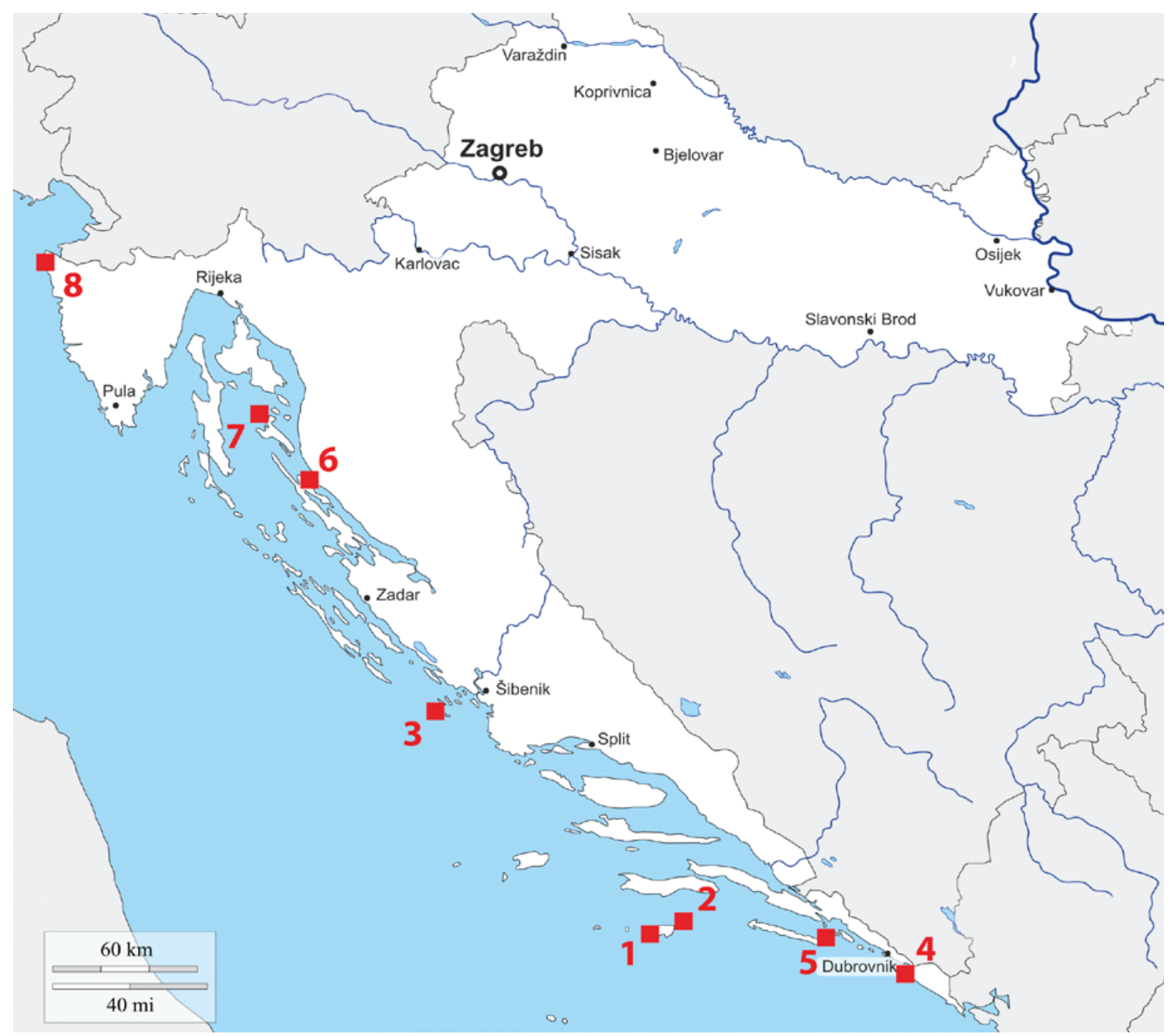

Karta 1. Karta s pozicijama arheoloških nalazišta na kojima su postavljeni zaštitni kavezi: 1. Lastovo - Za Planiku, 2. Lastovo - Saplun, 3. Žirje - Koromašno, 4. Cavtat - Supetar, 5. Mljet - Klačine, 6. Pag - Vlaška Mala, 7. Rab - Sorinj, 8. Umag - Buje (izradio: P. Dugonjić, 2021.) Map with positions of archaeological sites with protective cages: 1. Lastovo-Za Planiku, 2. Lastovo-Saplun, 3. Žirje-Koromašno, 4. CavtatSupetar, 5. Mljet-Klačine, 6. Pag-Vlaška Mala, 7. Rab-Sorinj, 8. Umag-Buje (P. Dugonjić, 2021)

Republički zavod, a u kojem predlažu zaštitu pojedinih podvodnih arheoloških nalazišta najmodernijom opremom, uz istovremeno osiguranje nalazišta od strane nadležnih tijela, ali i dozvolu za turističko ronjenje. ${ }^{4}$ Potrebno je istaknuti i kako se danas, među podvodnim arheolozima Mediterana, Hrvatska često ističe kao dobar primjer kada je $u$ pitanju zaštita podvodne kulturne baštine. Postoje brojni zakoni i pravilnici koji jasno definiraju tko prilikom ronjenja smije pristupiti podvodnoj baštini, istraživati je ili dokumentirati, a za nedozvoljene su radnje propisane prekršajne odredbe. ${ }^{5}$

Sve do 1980. godine bilo je uvriježeno mišljenje kako je veći dio podvodne kulturne baštine Republike Hrvatske devastiran, barem do dubine od $40 \mathrm{~m}$ koja označava granicu sportsko-rekreativnog ronjenja. Primjerice, otok Lastovo bio je jedan od otoka u čijem arhipelagu u Jugoslaviji nije bilo dozvoljeno ronjenje. Međutim, podvodna arheološka rekognosciranja podmorja Lastovskog otočja provedena 1987. i 1988. godine otkrila su kako su neka nalazišta izrazito devastirana. ${ }^{6}$ Iznimku predstavljaju dva nalazišta koja su prijavili lokalni ronioci. Jedno je od njih nalazište kod otočića Saplun, prvi put pregledano 1987. godine, a drugo je nalazište Za Planiku, koje je prvi put pregledano 1989. godine. ${ }^{7}$ Oba nalazišta čine skupine amfora čvrsto pričvršćene za morsko dno, a po jedno olovno sidro na svakom nalazištu ide $u$ prilog tomu da je riječ o brodolomima, a ne samo o potopljenom teretu. Vađenje amfora u ovim slučajevima nije dolazilo u obzir, ne samo zbog opasnosti od njihovog oštećenja nego i zbog toga što na otoku nije postojao muzej ili neka druga kulturna institucija u koju bi se arheološki materijal mogao pohraniti, dok su institucije na kopnu svoje skladišne kapacitete do tada već iscrpile. Još je jedan razlog, zbog kojeg je odlučeno ostaviti nalazišta na dnu 


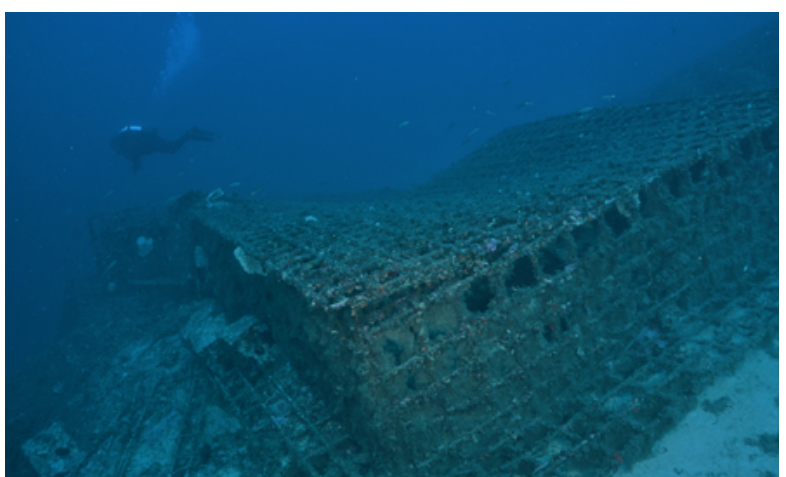

1. Otok Lastovo, nalazište Za Planiku, kavez prekriven obraštajem (arhiva HRZ-a, snimka: P. Dugonjić, 2016.)

Island of Lastovo, Za Planiku site, cage covered with overgrowth (HRZ Photo Archive, P. Dugonjić, 2016)

u stanju u kojem su zatečena, bio i njihov impresivan izgled. ${ }^{8}$ Međutim, 1990. godine primijećene su prve devastacije na nalazištu Za Planiku, ${ }^{9}$ nakon čega je Republički zavod za zaštitu kulturnih spomenika donio odluku o zaštiti cijelog nalazišta (površine oko $300 \mathrm{~m}^{2}$ ) pomoću građevinskih mreža pričvršćenih za dno betonskim blokovima, što je 1993. godine primijenjeno i na nalazištu Saplun. ${ }^{10}$ Nakon što se ovakav oblik zaštite ipak pokazao nedostatnim, s obzirom na to da je ubrzo skupina devastatora uništila mreže na nalazištu Za Planiku te otuđila deset amfora, a mnoge druge pritom oštetila, ${ }^{11}$ počinju se postavljati metalni kavezi čvršće konstrukcije. Ovi su kavezi izrađeni od željeznih cijevi na koje su dodatno pričvršćene mreže izrađene varenjem željeznih šipki. Počevši od 1990. godine, zaštitni su kavezi postavljeni na osam podvodnih arheoloških nalazišta, a to su: Za Planiku i Saplun $u$ arhipelagu Lastovskog otočja, Koromašno na otoku Žirju, otok Supetar ispred Cavtata, Klačine na otoku Mljetu, Vlaška Mala na otoku Pagu, Sorinj na otoku Rabu i Buje u blizini Umaga (karta 1). Kada je riječ o tipologiji pronađenog arheološkog materijala, treba istaknuti kako su na četiri nalazišta pronađene amfore tipa Lamboglia 2 (Za Planiku, Saplun, Klačine i Vlaška Mala), na dva su nalazišta pronađene grčko-italske amfore (Sorinj i Buje), na jednom su nalazištu pronađene afričke amfore tipa Keay XXV (Supetar), dok su na nalazištu Koromašno pronađene amfore tipa Dressel 43 i Riley Early Roman 1 (T. 1). Posao organizacije postavljanja svih zaštitnih kaveza vodio je Odjel za podvodnu arheologiju Hrvatskog restauratorskog zavoda, koji je do 2004. godine djelovao kao Odjel za zaštitu arheološke baštine Uprave za zaštitu kulturne baštine Ministarstva kulture i medija. U nastavku teksta spomenuta će se arheološka nalazišta kronološki obraditi te će se uz svako navesti njegove osnovne značajke.

\section{Arheološka nalazišta zaštićena kavezom}

Zaštita u obliku metalnih kaveza prvi je put primijenjena na već spomenutom nalazištu Za Planiku (poznatom i

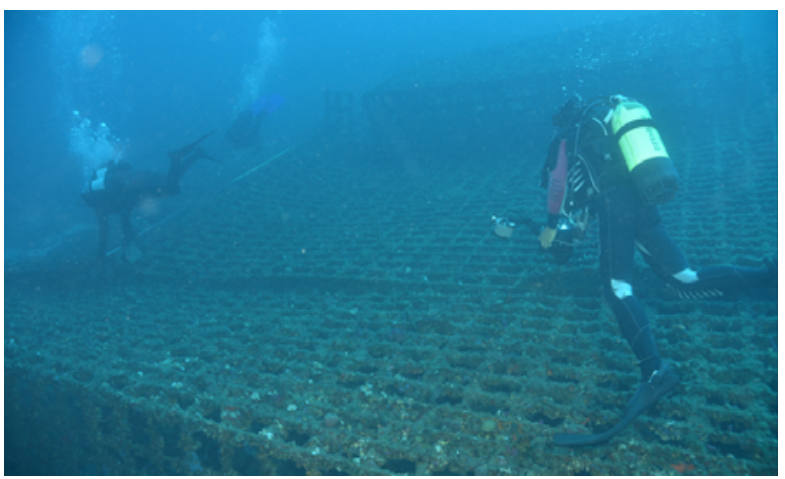

2. Otok Lastovo, nalazište Saplun, stanje zaštitnog kaveza 2016. godine (arhiva HRZ-a, snimka: P. Dugonjić, 2016.) Island of Lastovo, Saplun site, condition of the cage in 2016 (HRZ Photo Archive, P. Dugonjić, 2016)

kao Baške stijene i Baški rat ${ }^{12}$ ) 1990. godine. Nalazište je smješteno uz jugozapadnu obalu otoka Lastova i pruža se na strmom stjenovitom morskom dnu na dubini od 35 do $47 \mathrm{~m}$. Predstavlja ostatke antičkog brodoloma s teretom stotinjak amfora tipa Lamboglia 2 koje su srasle za morsko dno i koje se datiraju u 2. polovicu 1. stoljeća pr. Kr. Nalazište je teško uočljivo, a njegove dimenzije iznose 13 x 5 m. Pronađeno je u intaktnom stanju 1989. godine, no već su prilikom sljedećeg pregleda, godinu kasnije, utvrđeni tragovi devastacije. Iste je godine nalazište zaštićeno građevinskim armaturnim mrežama kojima je svrha bila tek spriječiti pristup nalazima. S obzirom na to da se veći dio nalazišta nalazi na $40 \mathrm{~m}$ dubine, a manji na $51 \mathrm{~m}$, zaštitna je mreža postavljena u dva dijela. Betonski su blokovi postavljeni tako da drže mreže, a s mrežama su spojeni željeznim spojnicama "U“ oblika, debljine $10 \mathrm{~mm}$, zatvorenim željeznim pločicama i maticama. Osiguranje od smicanja mreža izvedeno je čeličnim klinovima kojima je mreža praktično svojim krajnjim dijelovima pribijena uz stijenu, a sveukupna težina ove konstrukcije iznosila je 3000 kg. ${ }^{13}$ Arheološkim pregledima 1993. i 1995. godine nisu primijećene naknadne devastacije. Međutim, 1996. godine utvrđeno je da su improviziranim padobranima oslabljene zaštitne konstrukcije te je dio mreža maknut s nalazišta. Na tom je mjestu polugama razvaljen gornji okamenjeni sloj amfora, koji je tako otvorio rupu promjera $5 \mathrm{~m}$ iz koje su vađene amfore. Prema gruboj procjeni, otuđeno je između 20 i 30 amfora, mnoge su slomljene, a dio je bio ostavljen, pripremljen za vađenje. ${ }^{14}$ Iste su godine ove mreže zamijenjene jednostavnim željeznim kavezom postavljenim svega $1 \mathrm{~m}$ iznad nalazišta (sl. 1). ${ }^{15}$ Stare su mreže ostavljene na dnu, a tamo su i danas. Kavez je izrađen bez nosive konstrukcije, tako da su same stranice kaveza s četiri potporne šipke bile njegovi nosivi elementi. Ova je praksa izrade primjenjivana sve do 2011. godine. ${ }^{16}$ Sudeći prema visini kaveza, nije bilo predviđeno da ronioci ulaze unutra. ${ }^{17}$ 

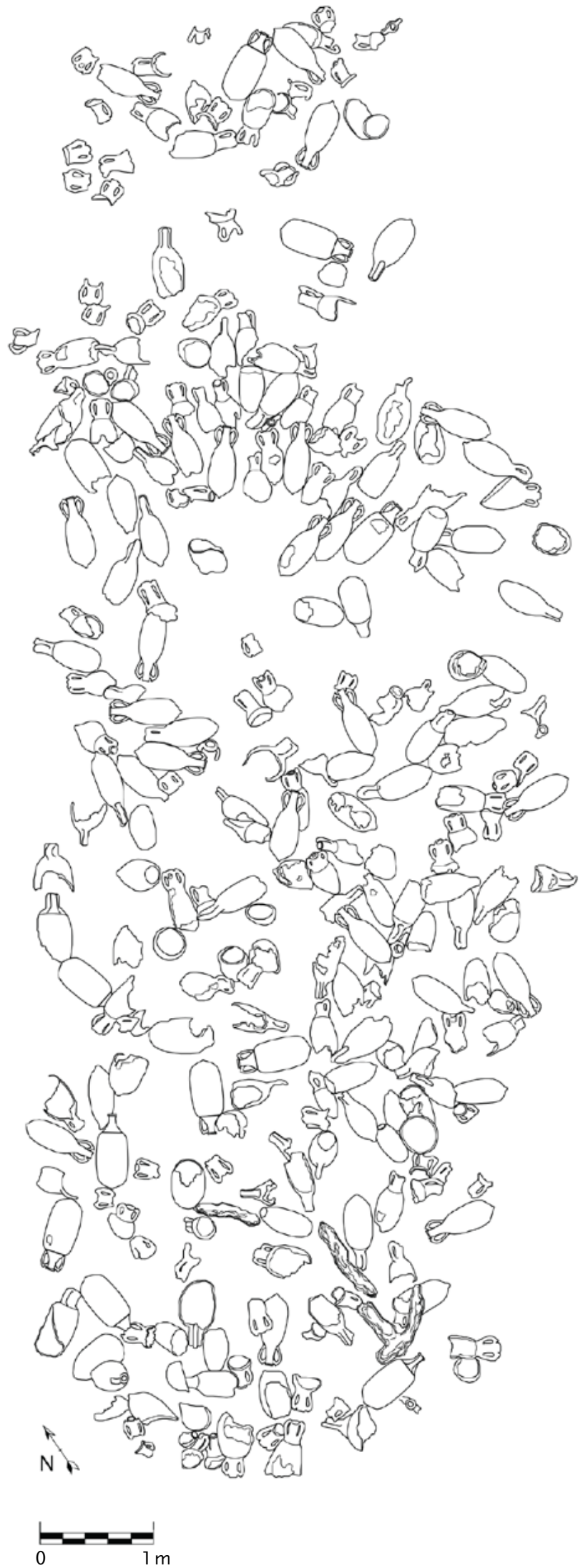

3. Otok Žirje, uvala Koromašno, plan nalazišta (arhiva HRZ-a, izradila: A. Skračić, 2017.)

Island of Žirje, Koromašno cove, site layout (HRZ Photo Archive, A. Skračić, 2017)
Nedugo nakon toga, uz otok Saplun kod otoka Lastova pronađeni su ostaci trgovačkog broda datiranog u 2. polovicu 2. stoljeća pr. Kr., s amforama prijelaznog tipa između grčko-italskih i Lamboglia 2. Nalazište je smješteno sa sjeverne strane istočnog rta otoka Saplun (otočje Donji Školji), na stjenovitom dnu, na dubini od 15 do $36 \mathrm{~m}$, a prvi su ga put prijavili lokalni ronioci 1987. godine. ${ }^{18}$ Sljedeće je godine nalazište nacrtno i fotografski dokumentirano te je provedeno manje sondažno istraživanje. Ustanovljeno je kako je na nalazištu vidljivo oko 110 cijelih ili gotovo cijelih amfora. Međutim, njihova loša kvaliteta znatno bi otežala vađenje, koje bi vjerojatno dovelo do njihovog pucanja. ${ }^{19}$ Brodski je teret uglavnom srastao s morskim dnom i prekriven je inkrustom pa su tijekom istraživanja izvađene samo četiri amfore koje su se mogle odvojiti od dna. Amfore tipa Lamboglia 2 (poznate i kao tipo uno) predstavljaju jedan od najčešćih brodskih tereta $u$ hrvatskom podmorju, a datiraju u kasno republikansko vrijeme 2 i 1 . stoljeća pr. Kr. Njihova tipologija proizlazi iz amfora grčko-italskog tipa, a proizvodile su se duž čitave zapadne jadranske obale. Danas se smatra da su imale zapremninu od oko $251^{20}$ i da su se najčešće koristile za prijevoz vina, premda su vjerojatno služile i za prijevoz drugih proizvoda. ${ }^{21}$ Prilikom vađenja predmeta, na zapadnoj je strani nalazišta pronađen i keramički louterion ili labrum ${ }^{22}$ za kojeg G. Kapitän navodi kako je korišten kao žrtvenik. Sudeći prema količini pronađenog tereta amfora, riječ je o manjem brodu na kojem nije vjerojatno da se louterion koristio za svakodnevno pranje, a kako je pronađen samo jedan, teško je povjerovati i da je bio namijenjen trgovini. ${ }^{23}$ Kao nalazište s najviše cjelovitih amfora na području otoka Lastova, privlačilo je pljačkaše i nesavjesne ronioce koji su između 1991. i 1993. otuđili desetak amfora, a na nalazištu su pronađene i poluge kojima su amfore vađene s dna. S ciljem sprječavanja daljnje devastacije, preko nalazišta je 1993. godine postavljena zaštitna mreža otežana betonskim blokovima. Ovaj je zaštitni kavez pregledan 1994. i 1995. godine, ali tragovi novih devastacija nisu uočeni. Stari je kavez 1997. godine zamijenjen modificiranim i čvršćim metalnim kavezom, ${ }^{24}$ dimenzija 15 x $8 \mathrm{~m}$, ukupne površine $100 \mathrm{~m}^{2}$, nepravilnog oblika koji prati konfiguraciju morskog dna (sl. 2). Prvi pregled novog kaveza proveden je 2007. godine, a već je do tada bio potpuno prekriven obraštajem. ${ }^{25}$ Posljednji su put oba kaveza u arhipelagu Lastovskog otočja pregledana 2016. godine, kada su na pojedinim mjestima otkrivena manja oštećenja od korozije. Oba su kaveza, dakle, tada ispunjavala isključivo svoju primarnu svrhu zaštite nalazišta, ali su potpuno izgubila svoju prezentacijsku komponentu. ${ }^{26} \mathrm{~S}$ obzirom na to da su oba nalazišta pronađena $u$ intaktnom stanju, imala su potencijal postati odlične destinacije za podvodni turizam. U vrijeme postavljanja na ovim nalazištima, metalni su kavezi bili najsigurniji i najučinkovitiji način 


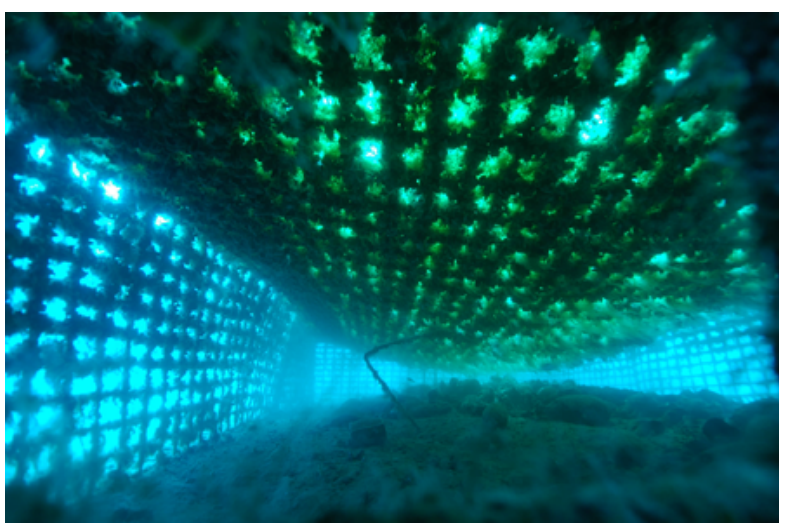

4. Otok Žirje, uvala Koromašno, oštećeni zaštitni kavez prekriven obraštajem (arhiva HRZ-a, snimka: I. Miholjek, 2011.) Island of Žirje, Koromašno cove, damaged cage covered with overgrowth (HRZ Photo Archive, I. Miholjek, 2011)

njihovog očuvanja. Ipak, postavljanjem kaveza umanjena je turistička i kulturna prezentacija samih nalazišta.

Sljedeći je zaštitni kavez postavljen 1998. godine na nalazištu antičkog brodoloma pronađenog iste godine prilikom klupskog ronjenja Ronilačkog centra Sava-Medveščak. Nalazište je smješteno na sjevernoj strani otoka Žirja, između uvala Muna i Koromašno. ${ }^{27}$ Nalazište se pruža na dubini od 38 do $43 \mathrm{~m},{ }^{28}$ a predstavlja teret više od 300 amfora položenih tako da jasno ocrtavaju formu potopljenog broda. Amfore se mogu pripisati tipovima Riley Early Roman 1 i Dressel 43 (Horn Handled Cretan), koje brodolom datiraju u vrijeme između 1. i 2. stoljeća ${ }^{29}$ $i$ koje su jedinstvene $u$ istočnom jadranskom podmorju (sl. 3). Nakon razmatranja mogućnosti istraživanja i vađenja arheoloških nalaza ili zaštite nalazišta in situ, odlučilo se za potonju opciju jer nadležni Muzej Grada Šibenika nije imao kapacitete za pohranu nalaza. Tijekom rekognosciranja šibenskog podmorja 2009. godine, kavez je pregledan i primijećeno je ulegnuće krova kaveza uslijed propadanja i popuštanja potpornih željeznih nosača ${ }^{30}$ (sl. 4). Prije postavljanja novog kaveza 2011. godine, stari je kavez uklonjen te je izrađena nacrtna dokumentacija, kao i dvodimenzionalni i trodimenzionalni fotomozaik nalazišta. Za razliku od prijašnjih kaveza koji nisu imali nosivu konstrukciju, nego su same stranice kaveza s četiri potporne šipke bile njegovi nosivi elementi, novi je kavez izrađen u nekoliko segmenata. Prvo je konstruirana nosiva konstrukcija od jakih L profila, koji čine kostur kaveza. Zatim su gornje horizontalne grede napravljene kao krov na dvije vode, a učvršćene su dodatnim kosim gredama, čime je postignuto rasterećivanje težine samog krova kaveza, te je ujedno izbjegnuto postavljanje vertikalnih potpornja, koji su na starom kavezu bili postavljeni direktno na amfore. Na ovu su nosivu konstrukciju zatim vijcima pričvršćene posebno izrađene mreže dimenzija $6 \times 3 \mathrm{~m}$. Svi su elementi potom vruće cinčani kako bi se omogućila najbolja zaštita od korozije. Težina je kaveza

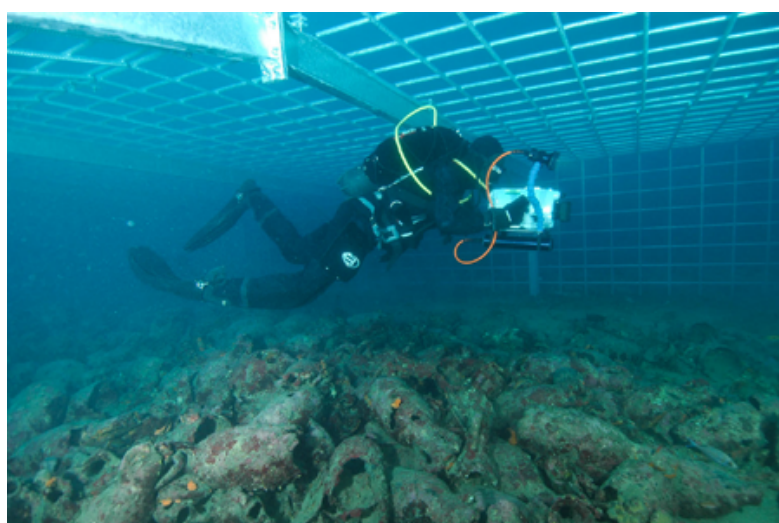

5. Otok Žirje, uvala Koromašno, ronilac unutar novog zaštitnog kaveza (arhiva HRZ-a, snimka: I. Miholjek, 2011.)

Island of Žirje, Koromašno cove, diver inside a new cage (HRZ Photo Archive, I. Miholjek, 2011)

$7 \mathrm{t}$, a njegove ukupne dimenzije iznose 17 x $9 \mathrm{~m}$. Visina varira između 2 i $3 \mathrm{~m}$, ovisno o konfiguraciji dna. $\mathrm{Na}$ bočnoj se strani kaveza nalaze vrata dimenzija 90 x 90 $\mathrm{cm}$, kako bi stručnjaci mogli pristupiti samom nalazištu. Ovime je otvorena i mogućnost ulaska turista, no isključivo uz nadzor. Na kavezu je također postavljena ploča koja označava kako je riječ o kulturnoj baštini, kao i ploča s imenom izvođača radova ${ }^{31}$ (sl. 5).

Zatim je 1999. godine postavljen zaštitni kavez kod otočića Supetra u blizini Cavtata, gdje je na dubini od $30 \mathrm{~m}$ pronađen trgovački brod s teretom sjevernoafričkih amfora tipa Keay XXV koje se datiraju u 4. stoljeće. ${ }^{32}$ Nalazište je otkriveno 1998. godine u blizini pličine Velika, a svojom površinom od oko $250 \mathrm{~m}^{2}$ predstavlja najveće i najbolje očuvano nalazište antičkog brodoloma do sada pronađeno $u$ istočnom Jadranu. ${ }^{33}$ Nalazište je koncentriranog ovalnog tipa, što znači da je veći dio amfora inkrustiran $u$ jednu cjelinu, a koncentracija samih nalaza ocrtava konture broda. ${ }^{34} \mathrm{U}$ površinskom je sloju vidljivo više od 600 amfora, ali se pretpostavlja da se ispod njega nalazi još barem 1200 amfora. ${ }^{35}$ Na nalazištu je 1999. godine proveden stručni uviđaj prilikom kojeg je izrađena preliminarna fotografska i videodokumentacija stanja nalazišta. Osim toga, uočeni su tragovi devastacije $u$ vidu rupa iz kojih su izvađene amfore, a nekoliko ih je bilo pripremljeno za vađenje. ${ }^{36}$ Stoga je, u svrhu zaštite, preko nalazišta iste godine postavljen kavez dimenzija 18 × 8 × 2,5 m s vratima na gornjoj strani za ulazak ronioca. Ovaj se zaštitni kavez 2010. godine urušio uslijed starosti i dotrajalosti. Novi je kavez izrađen 2011. godine, na isti način koji je opisan kod zamjene kaveza u uvali Koromašno na Žirju (sl. 6 i 7). Prvo je konstruirana nosiva konstrukcija od jakih L profila, koja je zatim obložena posebno izrađenim mrežama odgovarajuće veličine. Krov je izrađen na dvije vode te je podmetnut i dodatnim kosim gredama. Svi su elementi, također, vruće cinčani kako bi se omogućila najbolja 


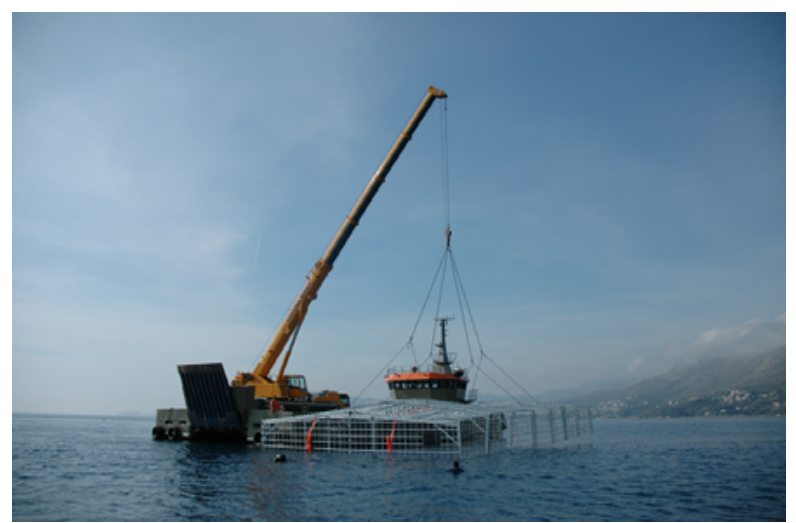

6. Otok Supetar, prijevoz kaveza brodom do lokacije nalazišta (arhiva HRZ-a, snimka: I. Miholjek, 2011.)

Island of Supetar, transport of cages by boat (HRZ Photo Archive, I. Miholjek, 2011)

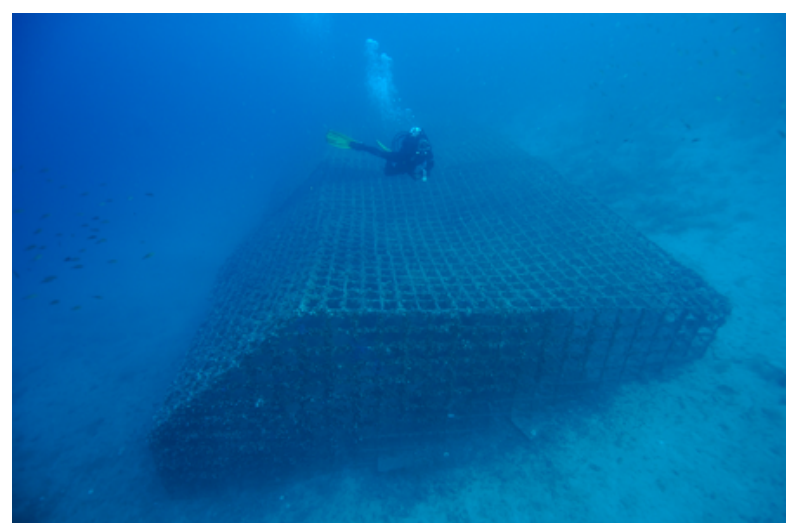

8. Otok Mljet, Klačine, stanje zaštitnog kaveza 2011. godine (arhiva HRZ-a, snimka: I. Miholjek, 2011.)

Island of Mljet, Klačine, condition of the cage in 2011 (HRZ Photo Archive, I. Miholjek, 2011)

zaštita od korozije. Težina je kaveza 10,5 t, dimenzije kaveza iznose 21 x $12 \mathrm{~m}$, dok mu visina varira između 2,1 i 3,5 m, ovisno o konfiguraciji terena. Kao i u slučaju novog kaveza u uvali Koromašno, i ovdje se na bočnoj strani kaveza nalaze vrata dimenzija 90 x $90 \mathrm{~cm}$, kako bi stručnjaci mogli pristupiti samom nalazištu. Ovime je otvorena i mogućnost ulaska turista, no isključivo uz nadzor. Također je postavljena ploča koja označava kako je riječ o kulturnoj baštini, kao i ploča s imenom izvođača radova. ${ }^{37}$ Zahvaljujući pogodnoj poziciji nalazišta ispred turističkog odmarališta u Cavtatu (antičkom Epidauru) te činjenici da se nalazi u neposrednoj blizini brodoloma s nalazom dolia, još je 2007. godine predloženo da se cijelo područje pretvori u prvi hrvatski arheološki park, što se, međutim, nije dogodilo. ${ }^{38}$ Ipak, danas je ovaj kavez jedini koji osim svoje primarne funkcije zaštite nalazišta ispunjava i onu promidžbenu. Tome svakako pridonosi blizina turističkog mjesta, što nije slučaj s, primjerice, kavezom u uvali Koromašno na Žirju, koji se nalazi na

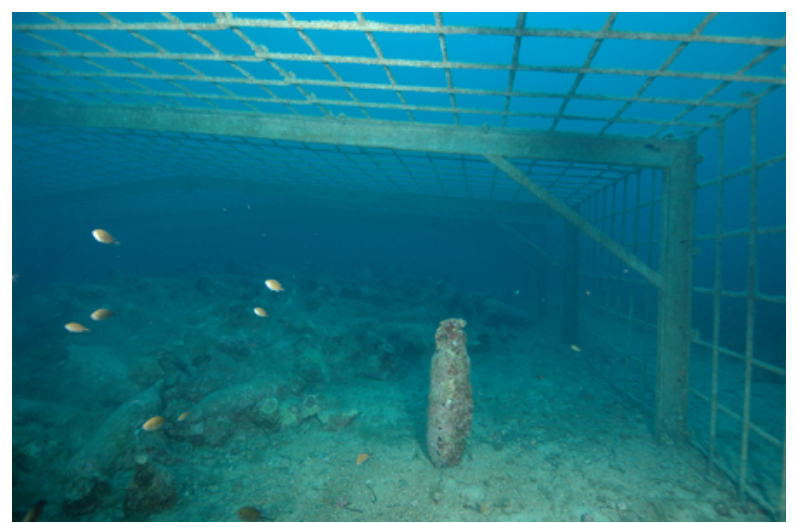

7. Otok Supetar, novi zaštitni kavez na nalazištu (arhiva HRZ-a, snimka: I. Miholjek, 2013.)

Island of Supetar, new cage on site (HRZ Photo Archive, I. Miholjek, 2013)

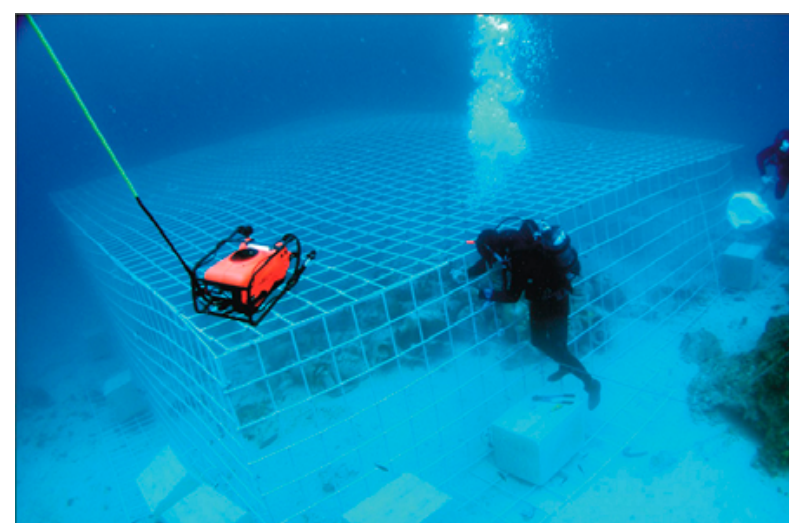

9. Otok Pag, zaštitni kavez na nalazištu u uvali Vlaška Mala (arhiva HRZ-a, snimka: D. Frka, 2004.)

Island of Pag, cage in the bay of Vlaška Mala (HRZ Photo Archive, D. Frka, 2004)

poprilično nezavidnoj poziciji, udaljen od većih turističkih odredišta.

Nalazište Klačine, smješteno na sjevernom dijelu otoka Mljeta na dubini od $30-35 \mathrm{~m}$, predstavlja još jedan potopljeni trgovački brod s teretom koji čini oko 150 amfora tipa Lamboglia 2 iz 1. stoljeća pr. Kr. Kavez je na ovom nalazištu postavljen 2001. godine, a kako je smješten na strmini, poput kaveza na Lastovu, i ovaj je konstruiran u kaskadnom trodijelnom obliku (sl. 8). Položen je 2,5 m iznad arheoloških nalaza, a površina zaštićenog područja iznosi 18 x $8 \mathrm{~m}$. Kavez nema ulaz za ronioce. ${ }^{39}$ Stanje kaveza pregledano je 2011. godine, kada je uočeno oštećenje na gornjem dijelu kaveza, nastalo uslijed propadanja metala djelovanjem mora. Oštećenje je tom prilikom privremeno sanirano, ali je nužno razmišljati o zamjeni samog kaveza kako bi on i dalje ispunjavao svoju primarnu funkciju zaštite podvodne kulturne baštine. ${ }^{40}$

Lokalni je ronilac 2004. godine prijavio dobro očuvano nalazište Vlaška Mala na dubini od 24 do $28 \mathrm{~m} \mathrm{u}$ 
Velebitskom kanalu, duž istočne obale otoka Paga. ${ }^{41}$ Riječ je o brodolomu s teretom $106^{42}$ amfora tipa Lamboglia 2. Iste je godine Odjel za zaštitu arheološke baštine proveo arheološko istraživanje, tijekom kojeg je nalazište fotografski i nacrtno dokumentirano, a pronađene su još i dvije olovne prečke sidra, mlinski kamen te olovni dubinomjer. Zaštitni je kavez na ovom nalazištu postavljen iste godine (sl. 9). Dimenzije kaveza iznose 12 x 10 $\mathrm{m}$, a visina $\mathrm{mu}$, zbog strmog terena, varira između 2 i 4 $\mathrm{m}$ kako bi gornja strana ostala horizontalna. Na gornjoj su strani kaveza mala vrata dimenzija 1 x $1 \mathrm{~m} .{ }^{43}$ Dražen Peranić iz Novalje, koji je pronašao i prijavio nalazište $i$ koji je tijekom posljednjih godina održavao kavez, primijetio je 2019. godine da nedostaje dio amfora. Djelatnici Međunarodnog centra za podvodnu arheologiju u Zadru sljedeće su godine obavili očevid na nalazištu i utvrdili novo stanje. Usporedbom nacrta iz 2004. godine i stvarnog stanja, dokumentirali su koje amfore nedostaju, koje su samo pomaknute, a koje su novootkrivene. Njihov je zaključak kako je grupa pljačkaša otuđila čak 40 amfora, a imajući na umu da je samo prijevoz tih amfora logistički izrazito zahtjevan, može se zaključiti kako je ova akcija pomno isplanirana. Ne treba umanjivati materijalnu štetu koju su pljačkaši svojim postupcima nanijeli i koja je doista velika, ali važnije je što je nalazište Vlaška Mala ovim radnjama izgubilo svoju kulturnu, povijesnu i znanstvenu vrijednost, odnosno nepovratno je uništeno. Nepovoljan položaj i velika udaljenost od većine ronilačkih centara na otoku Pagu i okolici utjecali su na budućnost ovog nalazišta. Unatoč pristupačnoj dubini, jedinstvenom prirodnom okruženju i ljepoti samog nalazišta, niti jedan od obližnjih ronilačkih centara nije zatražio izdavanje dopuštenja za obavljanje ronjenja u turističke svrhe. ${ }^{44}$

Nekoliko mjeseci nakon otkrića nalazišta Vlaška Mala, lokalni je ronilac Henrik Plješa prijavio nalazište s izuzetno dobro očuvanim ostacima antičkog brodoloma $\mathrm{s}$ teretom grčko-italskih amfora iz 2. stoljeća pr. Kr. Nalazište je smješteno sa zapadne strane rta Sorinj kod otoka Raba na dubini od 32 do $37 \mathrm{~m} .{ }^{45}$ Već dva mjeseca nakon provedenog prvog stručnog uviđaja na nalazištu, prilikom kojeg je u površinskom sloju zabilježeno 65 amfora, uočene su nedozvoljene ronilačke aktivnosti s namjerom pljačkanja nalazišta. Slijedom toga provedeno je prvo arheološko istraživanje nalazišta kako bi se izradila nacrtna, fotografska i videodokumentacija, ali i pronašlo najprikladnije rješenje za trajnu fizičku zaštitu. Tijekom istraživanja na nalazištu je dokumentirano 89 amfora, a pjeskovito dno ukazuje na moguću dobru očuvanost amfora i brodske konstrukcije $u$ dubljim slojevima. Primarno korištene za prijevoz vina, grčko-italske amfore vežu se uz helenistički period 4. i 2. stoljeća pr. Kr., s najranijim radionicama smještenima na prostoru Sicilije. Kasnije se njihova proizvodnja proširila i u južnu Italiju, Španjolsku, a zasigurno i na istočnu jadransku obalu, gdje se centar proizvodnje vjerojatno nalazio na otoku Visu. Pronađene su na svega sedamdesetak nalazišta antičkih brodoloma u Sredozemnom moru i desetak $\mathrm{u}$ jadranskom podmorju, zbog čega je nalazište kod rta Sorinj posebno važno. ${ }^{46}$ Amfore s ovog nalazišta pripadaju najkasnijoj fazi grčko-italskog tipa, koji se datira u 2. stoljeće pr. Kr. Karakteristične su zbog svog srcolikog oblika, a proizvodnja im se veže uz istočnu obalu Jadrana. U svrhu zaštite, na nalazištu je 2004. godine postavljen kavez trapezoidnog oblika, dužine $12 \mathrm{~m}$, širine $6 \mathrm{~m}$ i visine $2 \mathrm{~m}$, čija je nosiva konstrukcija izrađena od pocinčanih željeznih cijevi promjera $52 \mathrm{~mm}$, međusobno spojenih pocinčanim spojnicama. Stranice kaveza izrađene su varenjem narebrenih šipki od građevinskog željeza promjera 14 $\mathrm{mm}$, a na pokrovnoj je strani izrađen otvor s vratima dimenzija 1 x $1 \mathrm{~m}$, namijenjen ulasku ronioca $\mathrm{u}$ svrhu daljnjeg istraživanja i održavanja nalazišta. ${ }^{47}$ Prije spuštanja u more elementi kaveza premazani su zaštitnim bojama, a predviđena su i mjesta za postavljanje cinkove katodne zaštite. ${ }^{48}$ Konfiguracija morskog dna, u ovom slučaju strmog i pjeskovitog, uvjetovala je postavljanje kaveza upravo ovakvog tipa (sl. 10).

Posljednje u nizu nalazišta zaštićenih kavezom, nalazište je antičkog brodoloma s teretom grčko-italskog tipa amfora iz 2. stoljeća pr. Kr., smješteno kod pličine Buje, nedaleko od Umaga, na dubini od 14,5 m. Nalazište je smješteno na ravnom pješčanom dnu koje od pličine Buje lagano pada prema sredini kanala između pličine i kopna, ${ }^{49}$ u zoni u kojoj se skupljaju školjke Jakobove kapice i koja je lokalnim roniocima poznata još od 1980ih godina. Međutim, sporadične pljačke nalazišta, koje su u nekoliko navrata prijavljivane Odjelu za podvodnu arheologiju Hrvatskog restauratorskog zavoda, počele su 2000-ih, dok je prvi stručni uviđaj proveden 2006. godine. ${ }^{50}$ Tada je uočeno kako su nalazi koncentrirani na području dimenzija 22 x $14 \mathrm{~m}$, a na površini je dobro vidljivo oko 120 trbuha amfora, bez uočenih cijelih primjeraka (sl. 11). Izvađen je sitni pokretni materijal i predan Muzeju Grada Umaga. Na nalazištu su primijećene rupe nastale kopanjem, kao i improvizirani alat ilegalnih kopača. Prema mišljenju Marija Jurišića, vjerojatno je 1980-ih preko nalazišta prešao ribarski brod koji je alatom kojeg je vukao slomio grla amfora i razvukao amfore s primarne gomile. Ako je ta pretpostavka točna, onda se donji dio broda s cjelokupnim brodskim inventarom još uvijek nalazi pod pijeskom. U prilog ovoj pretpostavci ide i izgled nekih još zakopanih amfora, prema kojem je moguće procijeniti dubinu kulturnog sloja do još najmanje $100 \mathrm{~cm} .^{51}$ Arheološka istraživanja koja bi ovo potvrdila do danas nisu provedena. Zbog malene dubine nalazište je izrazito ugroženo pa su iste godine zatražena interventna sredstva od Ministarstva kulture i medija kako bi se provela preventivna zaštita $u$ vidu snimanja stanja nalazišta te prebacivanja pokretnih nalaza iz sektora B u sektor A, 


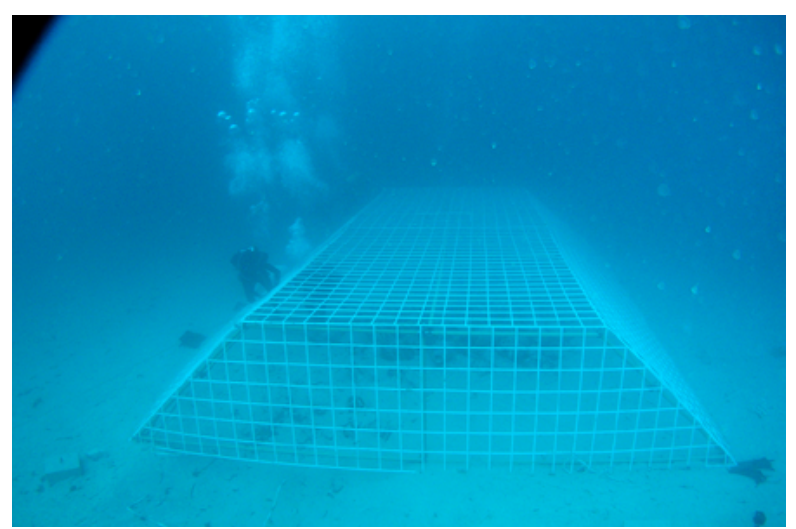

10. Otok Rab, zaštitni kavez nad nalazištem uz rt Sorinj (arhiva HRZ-a, snimka: D. Frka, 2004.)

Island of Rab, cage over the site near Cape Sorinj (HRZ Photo Archive, D. Frka, 2004)

koji je značajno manji. Naime, nalazište je u svom početnom stanju bilo preveliko za postavljanje zaštitnog kaveza pa je predloženo smanjiti prostor za postavljanje zaštite te zaštitu postaviti samo nad glavnom koncentracijom nalaza. Tijekom druge faze postavljen je zaštitni kavez čija se gornja strana može $u$ potpunosti otvoriti, kako bi se omogućilo daljnje sustavno istraživanje nalazišta. Nalazište ovog antičkog brodoloma izrazito je atraktivno, ne samo zbog očuvanih arheoloških nalaza i mogućnosti postojanja ostataka brodske konstrukcije u pijesku nego i zbog male dubine koja omogućava siguran posjet zainteresiranih ronioca i uključivanje nalazišta $u$ kulturno-turističku ponudu Istre. Također, njegova je lokacija vidljiva s kopna i lako se može nadzirati. ${ }^{52}$ U vrijeme postavljanja kaveza postojala je i ideja samofinanciranja daljnjih arheoloških istraživanja nalazišta školom podvodne arheologije, međutim ona, nažalost, nije zaživjela.

\section{Zaključna razmatranja}

Ideja zaštite podvodne kulturne baštine in situ postoji već vrlo dugo. Tijekom posljednjih pedeset i više godina podvodna se arheologija u Hrvatskoj razvijala usporedo s razvojem tehnike ronjenja i ronilačke opreme. Iako se na početku razmišljanja kako zaštititi podvodnu baštinu smatralo da je ona većim dijelom devastirana, s povećanom dostupnošću ronilačke opreme, njezine pojednostavljenosti i sigurnije upotrebe, dolazi do nebrojenih novih pronalazaka brodoloma i potopljene arhitekture, najčešće slučajnim pronalaskom, ali i sustavnim pregledima nadležnih službi. Postupno jača i svijest o važnosti podvodne kulturne baštine, o tome koliko nam ona toga može otkriti i koliko može obogatiti našu povijest. Ideja zaštite cjelovitih arheoloških nalazišta antičkih brodoloma in situ na morskome dnu zaštitnim metalnim kavezom javlja se početkom 90-ih godina prošlog stoljeća. Od tada do 2011. godine postavljeno je osam zaštitnih kaveza, a dva su zamijenjena novim. Tijekom 30-ak godina primjene

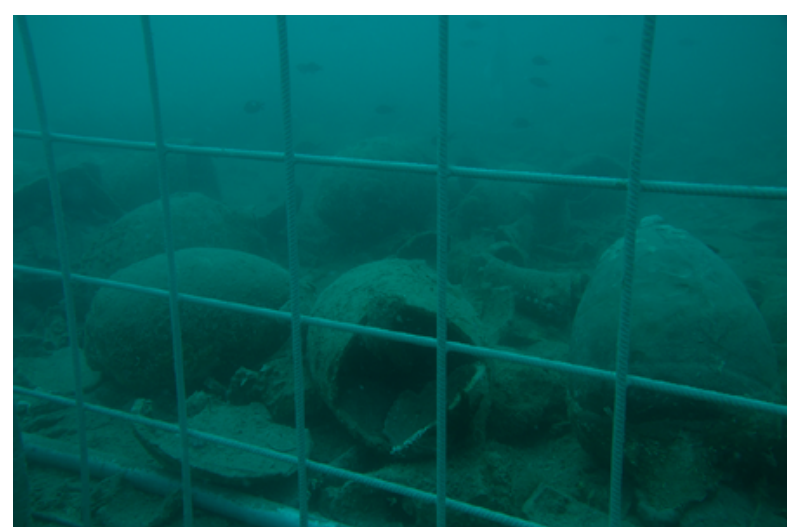

11. Umag, zaštitni kavez nad nalazištem antičkog brodoloma na pličini Buje (arhiva HRZ-a, snimka: I. Miholjek, 2007.) Umag, cage over the site of an ancient shipwreck in the Buje shoals (HRZ Photo Archive, I. Miholjek, 2007)

takve vrste mehaničke zaštite arheoloških nalazišta na morskome dnu, došlo se do različitih zaključaka o funkcionalnosti i smislenosti s obzirom na financijsku stranu. Naime, ovakva zaštita arheoloških nalazišta izuzetno je skupa. Osim upotrebe kaveza, primarno su se, kao sredstva fizičke zaštite arheoloških nalazišta koja bi onemogućila devastaciju, razvijale i ideje njihove upotrebe u obuci studenata arheologije i u stvaranju novih naraštaja podvodnih arheologa, kao i u testiranju nove opreme, prateći razvoj novih tehnologija s ciljem što sigurnijeg obavljanja posla i dobivanja što preciznijih podataka $u$ dokumentaciji.

Na nalazištu Za Planiku na otoku Lastovu najprije je postavljena metalna mreža koja je trebala štititi nalazište, ali ona nije bila dovoljna te je nakon nove devastacije zamijenjena većim i čvršćim kavezom. Tako je zadovoljena sigurnosna komponenta, dok se o prezentacijskoj nije razmišljalo. Nažalost, prilikom postavljanja zaštitnog kaveza, na dnu su ostavljene prvobitno postavljene željezne mreže, što je dodatno nagrdilo izgled samog nalazišta. Iskustvo ronilačkog centra koji ima odobrenje Ministarstva kulture i medija da obavlja ronilačku djelatnost $\mathrm{u}$ arheološkoj zoni Lastovskog otočja, nije pozitivno. Iako ima interesa za posjećivanje ostataka antičkih brodoloma u podmorju otoka Lastova, ronilački centar ne vodi turiste na ovo nalazište jer nije prezentacijski prihvatliivo. S obzirom na to da od 2006. godine postoji Park prirode Lastovsko otočje koji ima svoju nadzornu službu na moru, treba razmisliti o ideji uklanjanja ostataka metalnog zaštitnog kaveza. S takvom se idejom slažu i podvodni arheolozi i Park prirode Lastovsko otočje i ronilački centar, no završno mišljenje mora dati Ministarstvo kulture i medija. Na taj bi se način nalazište stavilo u funkciju turizma te bi se povećao sam nadzor češćim obilascima. Nalazište na otoku Saplunu u Lastovskom arhipelagu zaštićeno je većim kavezom, bolje konstruiranim, koji za sada ispunjava funkciju zaštite, no rijetko se posjećuje turistički jer se nalazi predaleko od samog ronilačkog 


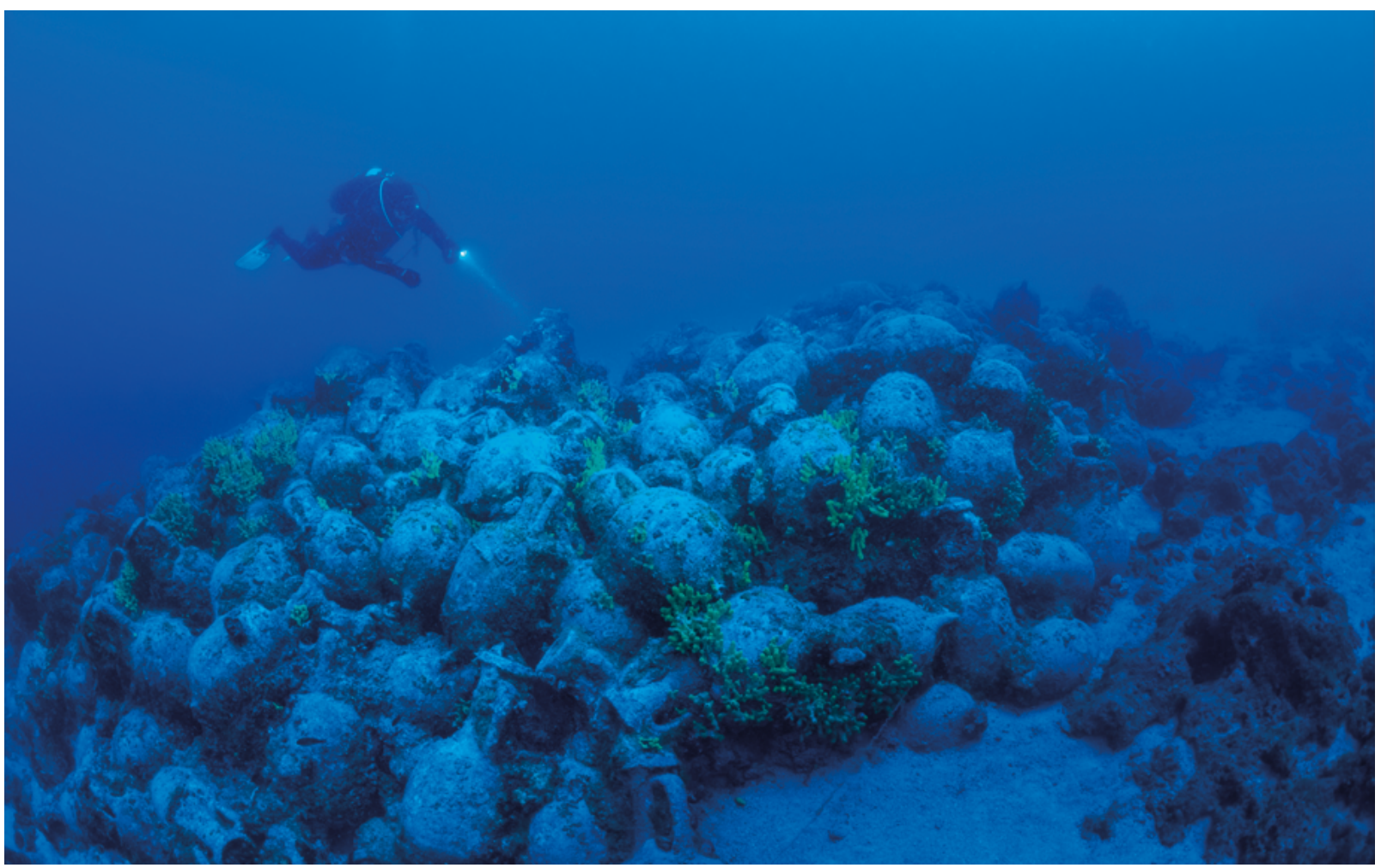

12. Otok Pag, nalazište antičkog brodoloma u uvali Letavica (snimka: A. Hodalič, 2018.)

Island of Pag, ancient shipwreck in the Letavica cove (A. Hodalič, 2018)

centra. Zaštitni kavez u podmorju otoka Žirje zamijenjen je 2011. godine jer se prethodni, postavljen 1998. godine, urušio zbog obraštaja florom i faunom, s kojim raste i težina krovne površine za nekoliko tona, te stoga potporni stupovi i same stranice zaštitnog kaveza ne mogu izdržati naprezanja uzrokovana dodatnom težinom. Ovaj primjer pokazuje kako je bilo potrebno 13 godina da težina obraštaja postane prevelika za sam zaštitni kavez. Na sreću, tijekom zamjene zaštitnog kaveza pregledano je nalazište te nisu pronađena oštećenja na amforama. Zamjenski je kavez napravljen drugačijom tehnikom, zaštićen je cinčanom zaštitom, što bi trebalo spriječiti koroziju metala i prirodni obraštaj barem za neko vrijeme. Pregledom 2015. godine, dakle četiri godine nakon njegovog postavljanja, ustanovljeno je da je zaštitni kavez obrastao u zelenu algu koju je more prirodnim putem donijelo do kaveza. Bez čvrstog obraštaja, ali s algama koje su visjele s kaveza po amforama, ostao je bez prezentacijske komponente. Bez redovitog čišćenja dolazi do zarastanja zaštitnog kaveza morskim organizmima. Nažalost, u Ministarstvu kulture i medija ne postoji program koji bi nadzirao postavljene zaštitne kaveze i skrbio o njihovoj funkcionalnosti. Isto je Ministarstvo financiralo postavljanje i zamjenu svih zaštitnih kaveza. Za razliku od nalazišta brodoloma s amforama ispred Cavtata, koje se nalazi blizu ronilačkih centara, nalazište u podmorju otoka Žirje nalazi se predaleko od turističkih centara te ne postoji interes da se vode turisti. To je šteta jer je nalazište sjajan primjer ostataka antičkog brodoloma s teretom amfora. Ispred Cavtata nalazi se, prema broju amfora, najveće nalazište u Jadranu, na kojem preko tisuću amfora leži na morskom dnu u formi koja odaje kako su bile transportirane u brodu. Stari je zaštitni kavez zamijenjen novim 2011. godine jer je krov zaštitnog kaveza postavljenog 1999. godine, izuzetno zarastao i otežao gornji dio. Urušavanju kaveza doprinijelo je i nesavjesno sidrenje brodova ronilačkih centara koji su imali odobrenje za ronjenje na ovom nalazištu. Naime, umjesto da se sidre pokraj zaštitnog kaveza, oni su se sidrili za kavez te je otpor brodova u moru dodatno utjecao na slabljenje konstrukcije. S druge strane, ovo je svijetli primjer organiziranog vođenja turista na arheološko nalazište pod morem te je u ovom slučaju, osim zaštitne, zadovoljena i prezentacijska komponenta. Godine 2001. postavljen je kavez u podmorju otoka Mljeta, koji zbog svoje velike udaljenosti od obližnjih ronilačkih centara, također nikada nije imao prezentacijsku komponentu. Iz istih razloga kao i kavezi kod Žirja i Supetra, i zaštitni je kavez na Mljetu propao. Oštećenje na krovu privremeno je sanirano 2011. godine, no nikada trajno, stoga je pitanje $u$ kakvom je kavez danas stanju kavez i koju funkciju ispunjava. Zaštitni kavez u podmorju otoka Paga, zbog svoje udaljenosti od ronilačkih centara, nije prezentacijski zaživio, a od 2019. godine narušena mu je i zaštitna komponenta. Naime, provaljeno je u kavez i otuđeno je na desetke amfora. Razmjeri ovakve devastacije upućuju na organizirani kriminal. Zaštitni 


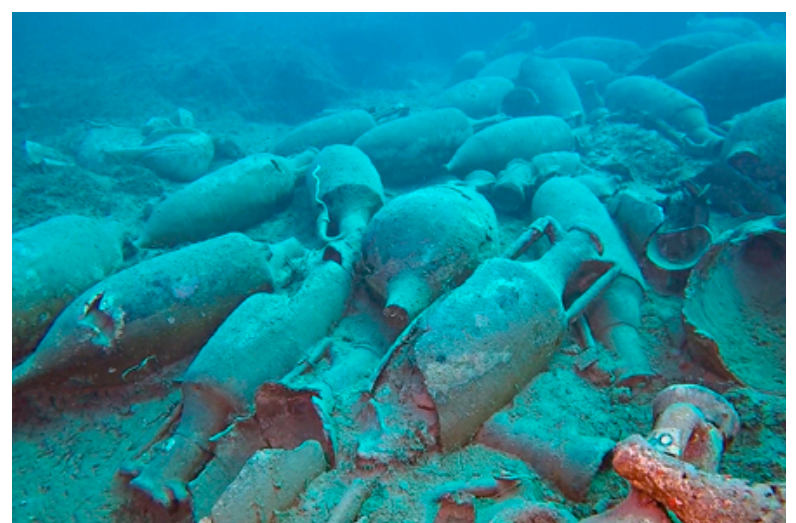

13. Otok Mljet, nalazište antičkog brodoloma u uvali Zaobraslo Prijeslo (arhiva HRZ-a, snimka: A. Voje, 2016.)

Island of Mljet, ancient shipwreck in the Zaobraslo Prijeslo cove (HRZ Photo Archive, A. Voje, 2016)

kavez u podmorju otoka Raba ima svoju zaštitnu ulogu, ali je slabo posjećen. Isto je i s nalazištem amfora zaštićenih kavezom kod pličine Buje kod Umaga. Zaštitni je kavez na ovom nalazištu tako konstruiran da se kompletan krov vrlo lako može ukloniti i nesmetano omogućiti podvodnim arheolozima i studentima da usavršavaju svoje vještine, da ispituju novu opremu za dokumentaciju i nove metodologije pri istraživanju. Iako su turisti svojedobno posjećivali arheološko nalazište, danas kavez ima samo zaštitnu funkciju. Od osam zaštitnih kaveza, danas postoje samo tri dopuštenja za ronjenje na kulturnoj baštini koja je izdalo nadležno ministarstvo. Jedno je od njih nalazište kod otočića Supetra ispred Cavtata, a druga su dva dopuštenja vezana uz arheološke zone na otocima Mljetu i Lastovu. Nažalost, danas se samo kavez kod Supetra iskorištava u turističke i promidžbene svrhe, dok nalazišta na Mljetu i Lastovu nisu reprezentativna pa se turisti tamo ne vode.

Problem zaštite podvodne kulturne baštine, u ovom slučaju antičkih brodoloma, nije jednostavan. Želja za zaštitom evoluirala je $u$ želju za pokazivanjem onoga što Jadran skriva. I imamo što pokazati, plovni put Jadranom uvijek je bio zanimljiv civilizacijama. Posljednjih je godina pronađeno nekoliko novih nalazišta. Riječ je o antičkim brodolomima kod otoka Paga i otoka Mljeta koji su izvrsno sačuvani. Nalazište kod otoka Paga (sl. 12) nalazi se ispred ronilačkog centa, a nalazište na otoku Mljetu (sl. 13) unutar Nacionalnog parka Mljet koji ima nadzornu službu na moru. Zaštita kavezom smislena je u slučaju suzbijanja mogućih devastacija, no svakako bi nagrdila ljepotu kompletno sačuvanih ostataka antičkih brodoloma. A ostaje i pitanje održavanja kako bi zaštitni kavezi ostali funkcionalni. S novim tehnologijama rađaju se i nove ideje. Tijekom nekoliko posljednjih godina razmišlja se o primjeni nadzornih bova, koje bi zamijenile kaveze. Bove bi posjedovale neku vrstu tehnologije koja može detektirati pokret, npr. hidrofon koji bilježi pokrete mjehurića zraka koje ispušta ronilac, a ne detektira pokret ribe. Postoje i druge ideje koje su još ili u fazi ideje ili razrade. Takve bi bove funkcionirale na način da svako neovlašteno ronjenje na nalazištu zabilježe te alarmiraju nadležne službe. No tko su u ovom slučaju nadležne službe? Nadležni konzervatorski odjeli koji su smješteni predaleko od nalazišta, pomorska policija, lučka kapetanija, obalna straža, koji svi imaju plovila, ali nemaju ronioce i stručnjake? Ronilački centar koji ima odobrenje nadležnog ministarstva za ronjenje? Potrebno je odgovoriti na mnogo otvorenih pravnih pitanja prije nego što zaživi ovakva vrsta zaštite podvodne kulturne baštine. Dakako, takve buduće vrste zaštite koštaju te je potrebno za svako nalazište posebno napraviti studiju kako bi se odredilo koja vrsta zaštite najbolje odgovara samom nalazištu. Zaštita bi ovisila o položaju nalazišta, dubini, vrsti morskog dna, mogućnosti nadzora, ali i posjećenosti turista, odnosno gospodarsko-ekonomskim aspektima. Najjeftinije je, tamo gdje je to moguće, nalazište pokriti morskim pijeskom i ostaviti ga za neka bolja vremena. No najjeftinije rješenje nije uvijek i najbolje te smatramo da podvodnu kulturnu baštinu trebamo pokazivati, a ne skrivati. Zaštita i prezentacija kulturne baštine nikada nije bila jeftina, a kulturnom baštinom treba i znati gospodariti. Kako vidimo, dosadašnja su iskustva različita; od ideja da se nalazište zaštiti željeznom mrežom, preko bolje konstruiranih kaveza koji mogu imati i prezentacijsku funkciju, kaveza koji se mogu otvoriti i omogućiti zainteresiranima nesmetan ulazak i rad na arheološkom nalazištu, do zaštite koja ne uključuje kavez, nego koristi suvremene tehnologije nadzora. Danas je dostupna i tehnologija koja, onima koji ne rone, virtualno može dočarati kako izgleda antički brodolom, a nama stručnjacima može pomoći u donošenju novih znanstvenih zaključaka. Za bilo koji oblik zaštite arheoloških nalazišta, službe koje skrbe o baštini trebaju imati razvijen program koji financijski može pratiti zaštitu nalazišta, koji stručnjacima omogućuje periodički pregled, čišćenje te, po potrebi, i zamjenu zaštite. Nažalost, takav program na nacionalnoj razini ne postoji, nego je sve na pojedincima koji u sklopu svojih radnih mjesta parcijalno vode brigu o pojedinom nalazištu, odnosno o zaštitnom kavezu. Još jedna komponenta zaštite, osim pravne i fizičke, edukacija je od malih nogu, kako bi svi shvatili važnost nasljeđa i na taj način doprinijeli zaštiti kulturnog bogatstva. Nažalost, iako je svijest o važnosti očuvanja podvodne kulturne baštine danas na većem nivou nego prije dvadesetak godina, još uvijek nije dovoljno razvijena. Bez obzira na pozitivna i negativna iskustva u zaštiti nalazišta metalnim kavezima, smatramo da primjena takve zaštite ipak ima svoju primarnu funkciju, ali da je potrebno i dalje razvijati nove ideje i pronalaziti najbolja rješenja za zaštitu i prezentaciju pojedinih nalazišta. 
Tabla 1. Tipovi amfora pronađeni na arheološkim nalazištima na kojima su postavljeni zaštitni kavezi: Lamboglia 2 - Za Planiku, Saplun, Klačine, Vlaška Mala; grčko-italske - Buje i Sorinj; Keay XXV - Supetar; Dressel 43 i Riley Early Roman 1 - Koromašno (izradio: P. Dugonjić, 2021.)

Types of amphorae found at archaeological sites with protective cages. Lamboglia 2: Za Planiku, Saplun, Klačine, Vlaška Mala; Greco-Italic: Buje and Sorinj; Keay XXV: Supetar; Dressel 43 and Riley Early Roman 1: Koromašno (P. Dugonjić, 2021)

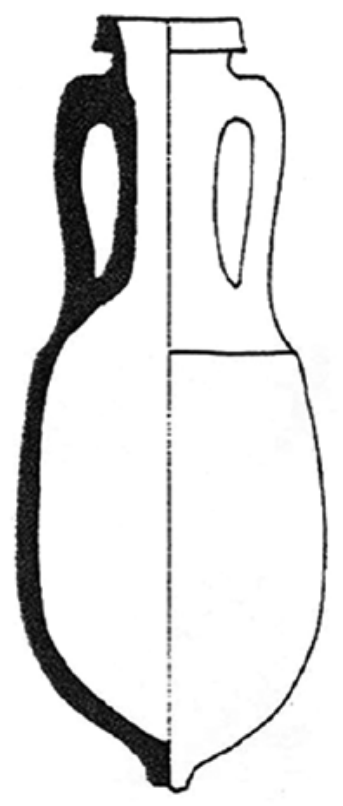

Lamboglia 2

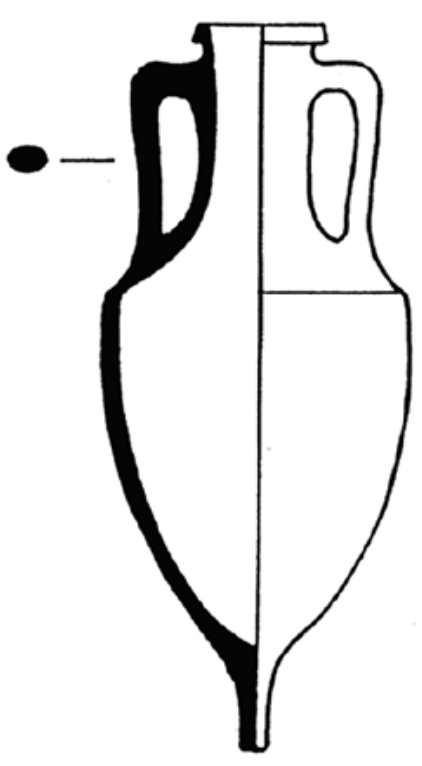

Grčko-italska
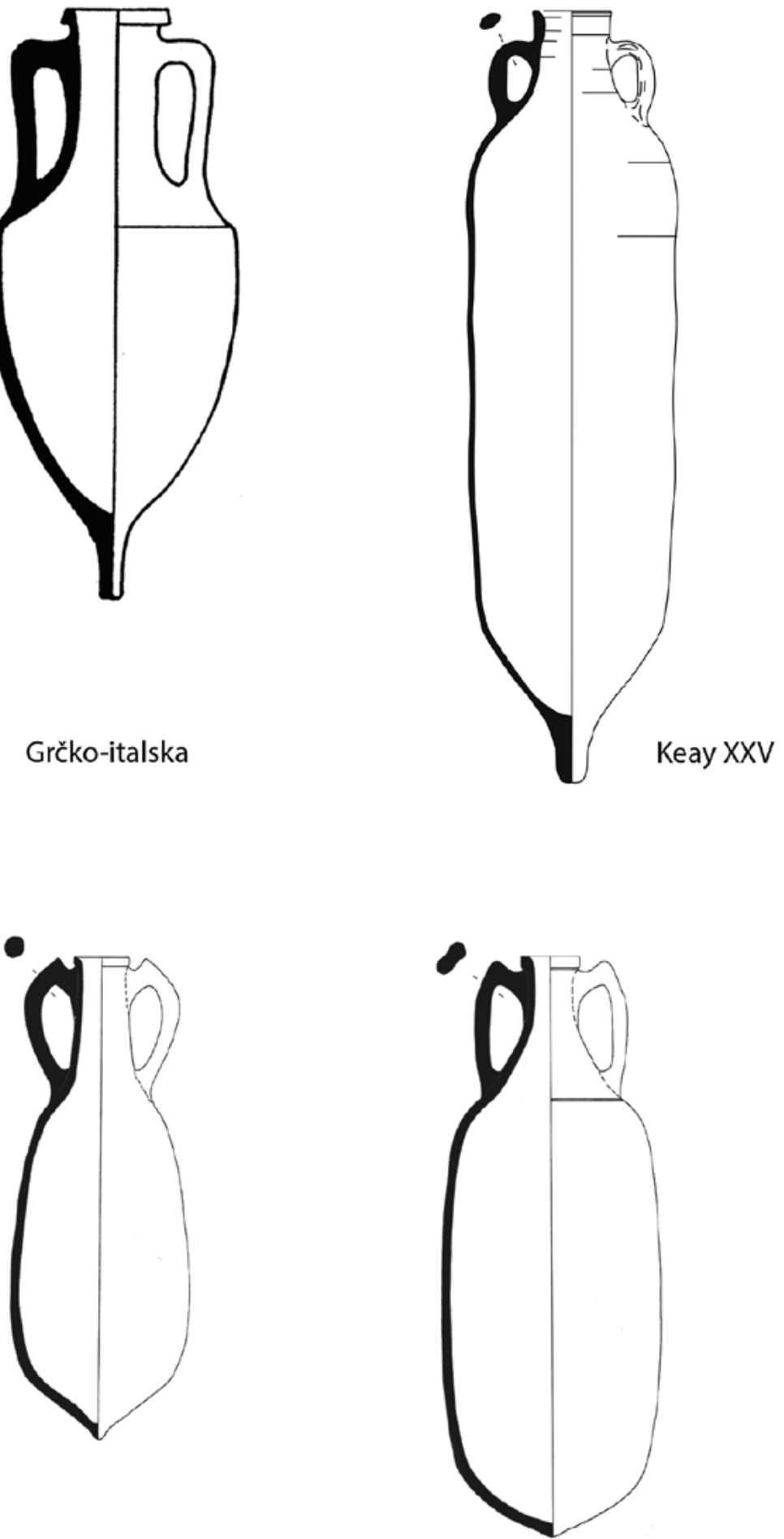

ER1

Dressel 43

Dressel 43

$50 \mathrm{~cm}$ 


\section{Bilješke}

1. VRSALOVIĆ, 1974, 30.

2. RADIĆ-ROSSI, $2014,45$.

3. PEŠIĆ, 2020, 20.

4. RADIĆ-ROSSI, 2014, 45.

5. PEŠIĆ, 2020, 20.

6. RADIĆ-ROSSI, 2001, 233-234.

7. RADIĆ ROSSI, 2001, 227-231.

8. RADIĆ-ROSSI, $2014,46$.

9. JURIŠIĆ, 2006a, 149.

10. RADIĆ-ROSSI, 2014, 46.

11. RADIĆ-ROSSI, 2014, 46.

12. RADIĆ ROSSI, 2001, 230-231.

13. JURIŠIĆ, ORLIĆ, 1990, 1-2.

14. MARIO JURIŠIĆ, 1996, 1.

15. RADIĆ-ROSSI, 2014, 47-48.

16. MIHOLJEK, 2012, 2.

17. RADIĆ-ROSSI, 2014, 47-48.

18. MIHOLJEK, 2019, 18.

19. JURIŠIĆ, ORLIĆ, 1988, 1.

20. KIRIGIN, KATUNARIĆ, ŠEŠELJ, 2005, 5.

21. MIHOLJEK, 2019, 18.

22. RADIĆ-ROSSI, 2014, 48.

23. RADIĆ-ROSSI, 1991, 160.

24. ZMAIĆ, 2009a, 19.

25. MIHOLJEK, 2007c, 12.

26. MIHOLJEK, 2017, 10.

\section{Literatura}

MARIO JURIŠIĆ, Stručno izvješće o uviđaju na devastiranom antičkom brodolomu na otoku Lastovu, Odjel za podvodnu arheologiju HRZ-a, Zagreb, 1996.

MARIO JURIŠIĆ, Ancient Shipwrecks of the Adriatic. Maritime transport during the first and second centuries $A D, B A R$ International Series 828, Oxford, 2000.

MARIO JURIŠIĆ, La protezione fisica dei siti archeologici sommersi del fondale marino nell'Adriatico croato, Archeologia subacquea in Croazia; Studi e ricerche, ur. Irena Radić-Rossi, Marsilio, Venezia, 2006a, 147-156

MARIO JURIŠIĆ, The maritime trade of the Roman province, u: Dalmatia: Research in the Roman Province 1970 - 2001, ur. David Davison, Vince Gaffney i Emilio Marin. BAR International Series 1576, Oxford, 2006b, 175-193

MARIO JURIŠIĆ, Izvještaj s rekognosciranja 11. - 13.4.2006. u akvatoriju Istre - pličina Buje, Odjel za podvodnu arheologiju HRZ-a, Zagreb, 2006c.

MARIO JURIŠIĆ, Radni prijedlog projekta - Umag, pličina Buje, akvatorij Istre, Odjel za podvodnu arheologiju HRZ-a, Zagreb, 2006d. MARIO JURIŠIĆ, MARIJAN ORLIĆ, Zaštitno podmorsko arheološko istraživanje lokaliteta kod otoka Sapluna, Lastovo, Odjel za podvodnu arheologiju HRZ-a, Zagreb, 1988.
27. ZMAIĆ, 2009b, 8.

28. ZMAIĆ 2009a, 19.

29. JURIŠIĆ, 2000, 67.

30. ZMAIĆ, 2009b, 8.

31. MIHOLJEK, 2012, 2.

32. JURIŠIĆ, 2006b, 189.

33. MIHOLJEK, 2007a, 64.

34. ORLIĆ, 1999, 3.

35. MIHOLJEK, 2007, 64.

36. ORLIĆ, 1999, 3.

37. MIHOLJEK, 2011, 4.

38. MIHOLJEK, 2007a, 62.

39. JURIŠIĆ, 2006a, 154.

40. ZMAIĆ, MIHOLJEK, 2011, 12.

41. RADIĆ-ROSSI, 2004a, 39.

42. PEŠIĆ, 2020, 22.

43. RADIĆ-ROSSI, $2014,51$.

44. PEŠIĆ, 2020, 21-23.

45. MIHOLJEK, $2007 \mathrm{~b}, 377$.

46. MIHOLJEK, 2007b, 377, 378, 380.

47. MIHOLJEK, 2007b, 380.

48. RADIĆ-ROSSI, 2004b, 12.

49. ZMAIĆ, 2007, 259.

50. JURIŠIĆ, 2006c, 1.

51. ZMAIĆ, 2006, 259.

52. JURIŠIĆ, 2006d, 3-4.

MARIO JURIŠIĆ, MARIJAN ORLIĆ, Izvještaj o postavljanju zaštitne mreže na lokalitetu "Pod Planiku", otok Lastovo, Odjel za podvodnu arheologiju HRZ-a, Zagreb, 1990.

BRANKO KIRIGIN, TEA KATUNARIĆ, LUCIJANA ŠEŠELJ, Amfore i fina keramika (od 4. do 1. st. pr. Kr.) iz srednje Dalmacije: preliminarni ekonomski i socijalni pokazatelji, Arheološki vjesnik, 01 (2005.), 7-24

IGOR MIHOLJEK, The Project of underwater archaeological park in Cavtat, u: Proceedings of the $13^{\text {th }}$ Annual Meeting of the European Association of Archaeologists (Zadar, 18. - 23. rujna 2007.), ur. Irena Radić-Rossi, Andrej Gaspari i Andrzej Pydyn, Zadar, 2007a, 61-67 IGOR MIHOLJEK, Podmorsko arheološko nalazište kod rta Sorinj na otoku Rabu, Histria Antiqua, 15 (2007b), 377-384

IGOR MIHOLJEK, Izvješće o podmorskom arheološkom rekognosciranju otoka Lastova i okolnih otoka u 2007. godini, Odjel za podvodnu arheologiju HRZ-a, Zagreb, 2007c.

IGOR MIHOLJEK, Okončani izvještaj o realizaciji programa zaštite i očuvanja kulturnog dobra br. 2-740-3-2/11., Odjel za podvodnu arheologiju HRZ-a, Zagreb, 2011.

IGOR MIHOLJEK, Stručno izvješće o izvedenim radovima na zamjeni starog zaštitnog kaveza novim na arheološkom lokalitetu kod otoka Žirje (antički brodolom 1./2. st.), Odjel za podvodnu arheologiju HRZ-a, Zagreb, 2012. 
IGOR MIHOLJEK, Izvješće o podvodnom arheološkom istraživanju i rekognosciranju na programu zaštite kulturnog dobra: Dubrovačko podmorje u 2016. godini, Odjel za podvodnu arheologiju HRZ-a, Zagreb, 2017.

IGOR MIHOLJEK, Konzervatorski elaborat za podvodna arheološka nalazišta na području Parka prirode Lastovsko otočje, Odjel za podvodnu arheologiju HRZ-a, Zagreb, 2019.

MARIJAN ORLIĆ, Izvješće Cavtat-Supetar 1999. - očevid antičkog brodoloma, Odjel za podvodnu arheologiju HRZ-a, Zagreb, 1999. MLADEN PEŠIĆ, Zaštita podvodnih arheoloških nalazišta - tužan primjer brodoloma u uvali Vlaška Mala, Potopljena baština, 10 (2020.), 19-24

IRENA RADIĆ-ROSSI, Three more louteria finds in the Eastern Adriatic, The International Journal of Nautical Archaeology, 20 (1991.), 155-160

IRENA RADIĆ-ROSSI, Arheološka nalazišta antičkog doba u podmorju otoka Lastova, u: Arheološka istraživanja na području otoka Korčule i Lastova: znanstveni skup, Vela luka i Korčula, 18. 20. travnja 1991., Izdanja Hrvatskog arheološkog društva , Zagreb, 20 (2001.), 227-236

IRENA RADIĆ-ROSSI, Skriveno blago Novalje - Podvodna baština 1, Zagreb, 2004a.
IRENA RADIĆ-ROSSI, Izvješće o dokumentiranju postojećeg stanja, probnom istraživanju i zaštiti nalazišta, otok Rab, it Sorinj, Odjel za podvodnu arheologiju HRZ-a, Zagreb, 2004b.

IRENA RADIĆ-ROSSI, Experience in current management of underwater cultural heritage in Croatia; the case of the protective cages, Archaeologia maritima Mediterranea, 11 (2014.), 45-62 DASEN VRSALOVIĆ, Istraživanja i zaštita podmorskih arheoloških spomenika u SR Hrvatskoj, Republički zavod za zaštitu spomenika kulture, Zagreb, 1974.

VESNA ZMAIĆ, Pličina Buje, Hrvatski arheološki godišnjak 3/2006, Zagreb, (2007.), 259-260

VESNA ZMAIĆ, Zaštita antičkih brodoloma „in situ“ - podmorski muzeji, u: Istraživanje podvodne kulturne baštine u Hrvatskoj - priručnik, Zadar, 2009a, 18-19

VESNA ZMAIĆ, Izvješće o arheološkom rekognosciranju Šibenskog podmorja 2009. godine, Odjel za podvodnu arheologiju HRZ-a, Zagreb, 2009b.

VESNA ZMAIĆ, IGOR MIHOLJEK, Izvješće o podvodnom arheološkom rekognosciranju dubrovačkog podmorja 2011. godine“, Odjel za podvodnu arheologiju HRZ-a, Zagreb, 2011.

\section{Summary}

Sara Fabijanic, Igor Miholjek

\section{IN SITU PROTECTION OF UNDERWATER ARCHAEOLOGICAL SITES: PROTECTIVE CAGES}

The seabed of the eastern Adriatic is full of archaeological sites and shipwrecks from various periods, from prehistory to modern history. But even though there are laws and regulations that clearly define who may, and under what conditions, access underwater cultural heritage, as well as prescribed provisions for illegal activities, many underwater archaeological sites have been devastated, and valuable archaeological material has been stolen.

In situ physical protection, the primary choice according to the UNESCO Convention on the Protection of Underwater Cultural Heritage, is now being used, since existing regulations have proved to be an insufficient method of protection. In Croatia, metal cages were first used in 1990, and so far eight archaeological sites have been protected: Za Planiku and Saplun in the Lastovo archipelago, Koromašno off the island of Žirje, the island of Supetar near Cavtat, Klačine off the island of Mljet, Vlaška Mala off the island of Pag, Sorinj off the island of Rab, and Buje near Umag.

The earliest cages were solely intended to prevent access to archaeological finds, and were made out of construction nets that were attached to the seabed with concrete blocks. Despite the use of this type of protection, the Za Planiku site was again ravaged. Afterwards, the construction of cages was changed so that the load-bearing structure was constructed first, and it was then lined with specially-made nets of appropriate size.

The paper will provide an overview of archaeological sites where protection cages have been used so far. The advantages and disadvantages of this method will be defined, bearing in mind the issue of cage maintenance, the threat to individual sites with regard to their location, and their use for tourism and promotional purposes. The reasons why cages will not be used for some newly-discovered ancient shipwrecks will also be explained.

KEYwORDS: protection of underwater archaeological sites, eastern Adriatic, metal cages, shipwreck, antiquity, devastation, endangerment, amphorae, cultural heritage 
